\title{
УДК 330.83
}

Михальський Ю. В., e-mail: myhalski@gmail.com,ORCID ID: 0000-0002-1504-2604, Researcher ID: F-1372-2019, к.і.н., дои., зав. кафедри історії $i$ політологї̈, Львівський торговельно-економічний університет, м. Львів

\section{Миронова М. I.,}

e-mail:myronowa@gmail.com, ORCID ID: 0000-0003-1438-4394,

к.е.н., дои. кафедри теоретичної та прикладної економіки, Львівський торговельноекономічний університет, м. Львів

\section{ФОРМУВАННЯ ІДЕЇ УКРАЇНСЬКОГО ІНСТИТУЦІОНАЛІЗМУ В НАЦІОНАЛЬНІЙ КООПЕРАТИВНІЙ ДУМЦІ КІНЦЯ ХІХ - ПОЧАТКУ ХХ СТОЛІТТЯ}

\begin{abstract}
Анотація. Зростаюча в останні роки актуалізація інституційної економічної проблематики є переконливим свідченням посилення впливовості та авторитету інституційного напряму економічної теорії у світовому та вітчизняному науковому середовищі. Незважаючи на те, що у наукових праиях сучасних і зарубіжних економістів, вчених досить повно розкрито теоретико-методологічні аспекти інституційної теорії, потребує подальщого вивчення та обтрунтування інституційний напрям в сучасній економічній науці.

У статті розглядаються історико-методологічні засади формування ідеї інституиіоналізму в національній кооперативній думиі України, які формуються з другої половини XIX - першої половини ХХ cm. Проаналізовано чинники виникнення інституціоналізму та неоінституціоналізму. Сконцентровано увагу на ідеях інституиіоналізму в контексті формування класичної політичної економії в Україні. Автори підкреслюють необхідність адаптаиії аналізу соиіально-економічних інституиій у спадщині класичної політичної економії в Україні ХХ сm. до створення иілісної концепиї̈ генезису й еволюиії інституціоналізму в украӥнській економічній думиі. Наслідуючи кращі традиції європейської економічної науки, украӥнські вчені намагалися враховувати соиіальні суперечності, потребу демократичного реформування суспільних відносин у своїх праиях. Автори приходять до висновку, щьо у першій половині ХХ ст. українські економісти проголошували ідеї, співзвучні з ідеями інституціоналізму. Вони прагнули розширено трактувати предмет політичної економії, залучаючи до наукового аналізу морально-етичні, духовні, правові та інші фактори; здійснювали спроби дослідити мотивацію економічної поведінки людини та ї̈ обмеження.

У статті виокремлено особливості формування феномена інституціоналізму в украӥнській економічній думиі як базису для збереження самоідентичності украйнців. Розглянуто історичні еволюиійні зміни в господарській самоорганізації украӥнців. Досліджено соціально-психологічні та морально-культурні аспекти украӥнського національного інституиіоналізму. Вивчається вплив інституціоналізаиії на забезпечення начіонального господарсько-кооперативного руху. Визначено перспективні напрями подальших наукових досліджень у иій галузі.
\end{abstract}

Ключові слова: інституціоналізм, неоінституціоналізм, інституція, кооперація, кооперативний pyx.

Mykhalskyi Y.V.,

e-mail: myhalski@gmail.com, ORCID ID: 0000-0002-1504-2604, Researcher ID: F-1372-2019, Ph.D., Associate Professor, Head of the Department of History and Political Science, Lviv University of Trade and Economics, Lviv 
Myronova M. I.,

e-mail: myronowa@gmail.com,ORCID ID: 0000-0003-1438-4394,

Ph.D., Associate Professor of the Department of Theoretical and Applied Economics, Lviv University of Trade and Economics, Lviv

\title{
THE FORMATION OF THE UKRAINIAN NATIONAL COOPERATIVE INSTITUTIONALISM IDEA IN THE NATIONAL COOPERATIVE OPINION OF THE LATE XIX-EARLY XX CENTURY
}

\begin{abstract}
The growing actualization of institutional economic problems in recent years is a convincing evidence of the strengthening of the influence and authority of the institutional direction in the world and national economic theory. In spite of the fact that in scientific works of modern and foreign economists, scientists quite fully disclosed theoretical and methodological aspects of institutional theory, requires further study and justification of the institutional direction in modern economic science.

The article examines historical and methodological foundations of the institutionalism idea formation in the national cooperative opinion of Ukraine, which are formed in the second half of XIX - the first half of the $X X$ century. The factors of the emergence of institutionalism and neo-institutionalism are analyzed. Attention is focused on the ideas of institutionalism in the context of the formation of classical political economy in Ukraine. The authors emphasize the need to adapt the analysis of socio-economic institutions in the legacy of classical political economy in Ukraine of the twentieth century to the creation of a holistic concept of the genesis and evolution of institutionalism in Ukrainian economic thought. Inheriting the best traditions of European economic science, Ukrainian scientists tried to take into account social contradictions, the need for democratic reform of public relations in their works. The authors conclude that in the first half of the twentieth century Ukrainian economists proclaimed ideas consonant with the ideas of institutionalism. They sought to interpret the subject of political economy in a broad way, involving moral, ethical, spiritual, legal and other factors in scientific analysis; they made attempts to investigate the motivation of human economic behavior and its limitations.

The peculiarities of the formation of the phenomenon of institutionalism in Ukrainian economic thought as a basis for preserving Ukrainian self-identity are singled out. Historical evolutionary changes in the economic selforganization of Ukrainians are considered. The socio-psychological, moral and cultural aspects of the Ukrainian national institutionalism are studied. The influence of institutionalization on the national economics is examined. The perspective directions of further scientific researches in this direction are determined.
\end{abstract}

Key words: institutionalism, neoinstitutionalism, institution, cooperation, cooperative movement.

\section{DOI: https://doi.org/10.36477/2616-8510-2019-16-17}

Постановка проблеми. Методологія інституціоналізму використовує та інтегрує інструментарій різноманітних дисциплін, в першу чергу психології, соціології, історії, філософії, права тощо. Саме використання цієї методології дозволяє глибоко і всебічно дослідити інституційне поле процесу формування українських господарсько-кооперативних товариств на українських землях другої половини XIX - першої половини XX ст.

Аналіз останніх досліджень і публікацій. Методологічні засади українського інституціоналізму та історичні аспекти формування наукових поглядів інституціоналізму в українській економічній думці знайшли висвітлення у працях таких видатних економістів-істориків як Степан Злупко [4; 5], Ілля Витанович [3], Борис Мартос [6], Михайло Туган-Барановський [11] та ін. Поряд з цим, вимагає наукового опрацювання питання розвитку теорії інституціоналізму в економічній думці Галичини 2-ї половини XIX 1-ї половини XX ст., також потребують дослідження соціально-психологічні та морально-культурні аспекти українського національного інституціоналізму.

Мета дослідження. Метою статті $є$ висвітлення та наукове обгрунтування формування методологічних засад інституціоналізму в економічній думці України 2-ї половини XIX - 1-ї половини $\mathrm{XX}$ ст. та вивчення впливу інституціоналізації на забезпечення національного господарського руху. 
Виклад основного матеріалу дослідження. Інституціоналізм - напрям в економічній науці, який бере в основу аналізу не лише економічні проблеми, але й пов'язує їх 3 проблемами правовими, політичними, соціальними, етичними та ін. Фундатором школи інституціоналізму вважається Торстейн Бунде Веблен, який, використовуючи філософське осмислення економічних процесів та опираючись на доктрину Канта, розширив тлумачення предмета політичної економії [10, с. 59-61].

На наш погляд, виникнення інституціоналізму було обумовлено такими чинниками (рис. 1):

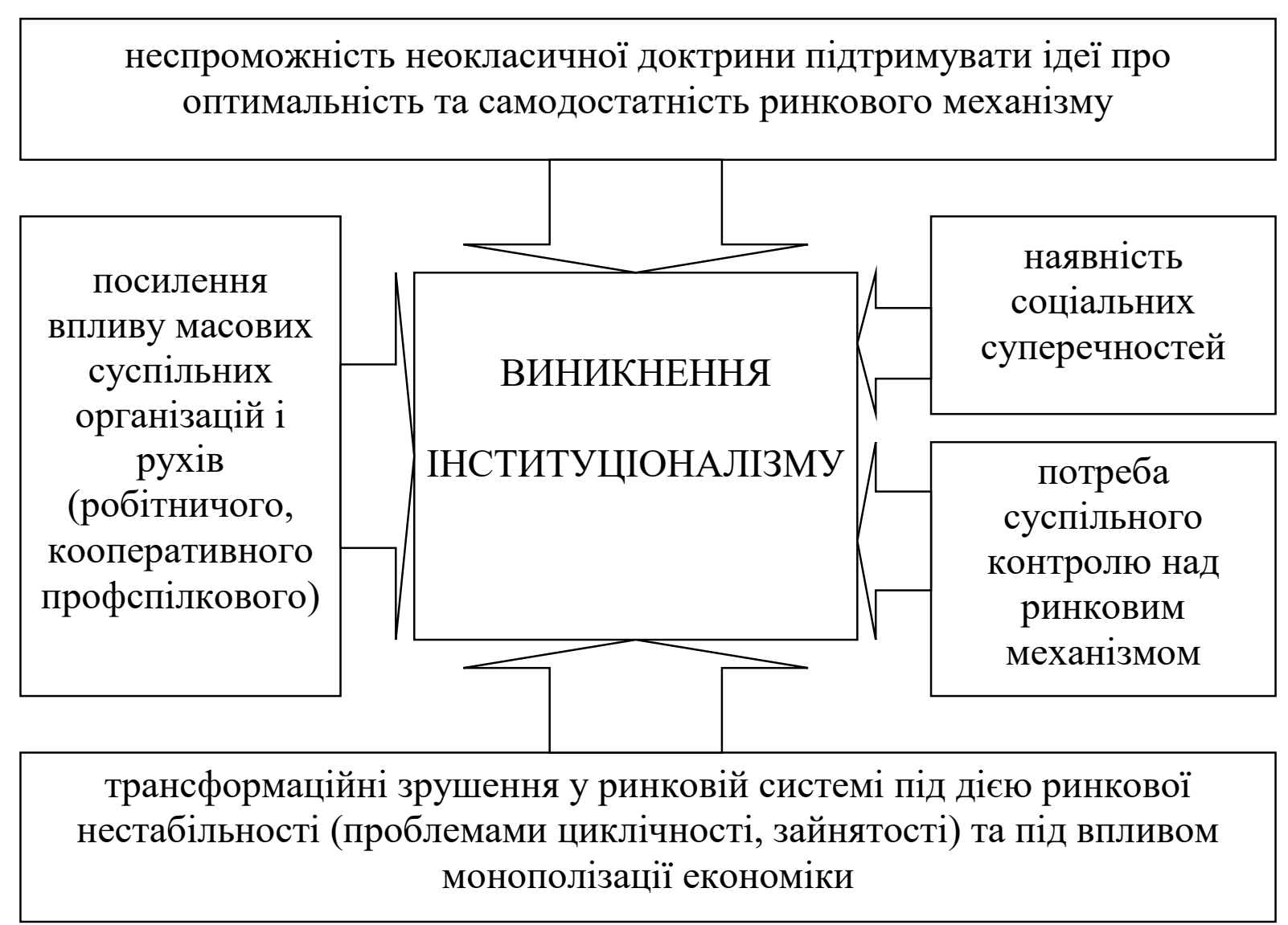

Рис. 1. Чинники виникнення інституціоналізму (авторська розробка)

Неоінституціоналізм, тобто нова інституціональна економічна теорія, яка була розвинута i започаткована нобеліантом у галузі економіки Дугласом С. Нортом, передбачає, що економіка функціонує в певних інституціональних рамках, причому ідеологія і культура значною мірою визначають і впливають на економічний розвиток [12]. У науковій зарубіжній літературі неоінституціоналізму часто акцентується на актуалізації формування широкого інституційного поля, яке передбачає відродження самобутніх засад національної господарської культури.

Підневільний статус українських земель, обумовлений пануванням чужих імперських держав, повністю визначив специфічні умови національного розвитку, який проявився у формуванні феномена інституціоналізму в українській економічній думці, який у свою чергу став потребою збереження самоідентичності українців.

Українська економічна думка розвиває цінності інституціоналізму в контексті загальноцивілізаційного процесу. Зокрема, представники Київської школи політекономії чітко окреслили поняття, які використовує інституціоналізм. Ще більш грунтовно базові цінності інституціоналізму використовує український вчений з світовим ім'ям Михайло Іванович Туган-Барановський. Він використовував міждисциплінарний методологічний інструментарій інституціоналізму (історію, психологію, соціологію тощо), аналізуючи і досліджуючи економічні процеси [4]. Методологію інституціоналізму він практикує у фундаментальному дослідженні «Соціальні основи кооперації» [11], у першому розділі якого обгрунтовується загальне вчення про кооперацію, насамперед тут мова йде про соціальний ідеал кооперації. Кооперативні підприємства, на думку вченого, це, по суті, єдина форма господарської організації, зорієнтована на зміну існуючої системи господарства за допомогою свідомих 
зусиль широких суспільних груп. Вагоме значення даного дослідження $є$ розкриття соціальної природи $\mathrm{i}$ політичної позиції господарської кооперації. Зокрема, Михайло Туган-Барановський, обгрунтовуючи співвідношення кооперації і політики, зазначає, що кооперація не $є$ асоціальною організацією. У ній соціальні інтереси віддзеркалюються ще більше, ніж це стосується політичних партій. Разом 3 тим вчений застерігає від об'єднання кооперації з політичною партією, оскільки таке об'єднання не є корисним: в результаті об'єднання і партія, і кооперативи, тобто обидві сторони [11].

За умов панування чужих держав в Галичині українська спільнота через кооперативний рух самореалізувалась, українці отримали економічну незалежність за умови відсутності державності. 3 кооперативним рухом в Східній Галичині тісно пов'язана як теорія, так і практика інституціоналізму, який відзначається реальними визначними постатями та теоретико-організаційним і практичним досвідом.

Одним із фундаторів інституціоналізму в кооперативному русі є Микола Васильович Левитський, який заохочував невеликі селянські господарства до спільного господарювання, побудованого на принципі добровільності. Він вважав, що «кооперація є найліпше і найкраще виявлення людського генія в межах соціально-економічного будівництва» [3, с. 106]. Саме на добровільних засадах, які пропонував Микола Левитський, розвивався артільний рух на Херсонщині, а дальше - поширився на Донеччину, Катеринославщину, Канівщину, Чернігівщину, Полтавщину. На засадах, сформульованих Миколою Левитським, артільний рух поширився також на етнічні російські землі.

Микола Левитський намагався реалізувати чітко сформовані власні науково-ідейні засади кооперації з використанням і розбудовою артільних господарств. На його погляд, артілі, які виникали і розвивалися, мали стати інституційним зародком нової моральної і виробничої організації. Микола Левитський зауважував: «Всі завоювання соціального прогресу по суті, здобуті не стільки економічними факторами, скільки силами моральними і ... перемагав зрештою не той, хто був сильніший економічно, а той, хто був сильніший морально» [3, с. 107]. Разом з тим, важливим $\epsilon$ те, що економічний розвиток він аналізував і розглядав з еволюціоністських позицій, оскільки «історія жодних різких кроків не знає», при цьому він акцентував увагу на демократично-республіканському дусі українського народу, який в кінцевому рахунку прагне створити устрій життя без пана і хлопа» [3, с. 107]. Артільна господарка, яку пропагував Микола Левитський, розвивалася в контексті використання досвіду країн Свропи і Америки. Микола Левитський як теоретик і практик сформував низку проектів про організацію кредитних, споживчих і кооперативних спілок, ремісничих і землеробських артілей, створення товариств сприяння артілям, артільних лавок і кас різних типів, виставок сільськогосподарських знарядь, тимчасових складів товарів тощо.

Серед українських кооператорів з інституціоналістським підходом необхідно відзначити і Бориса Миколайовича Мартоса, погляди якого сформувалися під впливом Миколи Левитського. Вченийкооператор звертав увагу на важливе значення кооперації для української нації, наголошуючи при цьому, що це значення особливо важливе в контексті «боротьби за самостійне економічне становище, за визволення од залежності економічної, за усунення визиску в дорозі обміну...» [6, с. 5]. Особливу роль при формуванні Миколи Левитського як науковця-кооператора відіграла діяльність Кооперативної Комісії при Полтавському Сільськогосподарському Товаристві, яке очолював Олександр Русов.

Борис Мартос, розвиваючи кооперативну теорію, в одній з своїх праць звертає увагу на те, що «в житті дуже рідко можна зустріти те чи інше явище в чистому вигляді, тому дуже часто кооперативи, які доводиться зустрічати на практиці, в деяких відношеннях відступають від того чистого типу, що дає теорія» [6, с. 47], при цьому він акцентує увагу на особливостях господарської кооперації порівняно 3 іншими економічними господарськими системами. Український вчений аналізує статути кредитних кооперативів, права і обов'язки членів, досліджує статутні та організаційні питання кооперативного руху, разом 3 тим він створив свою класифікацію кооперативів, детально проаналізував і описав кожну 3 кооперативних господарських форм, при цьому використовуючи як український, так і зарубіжний матеріал.

Надзвичайно важливим для практики кооперативної діяльності є те, що Борис Мартос приділяє особливу увагу кадровому питанню, при цьому він звертає увагу, що працівники господарської кооперації обов'язково повинні бути високофаховими, а свою діяльність вони повинні вибудовувати на принципі високих моральних засад. У цьому контексті він писав: «Для розвитку кооперації потрібні досвідчені керівники та добре підібраний фаховий персонал... В першу чергу керівник кооперативної установи, повинен бути людиною порядною. Розум, досвід та енергія людини нечесної принесуть кооперації не користь, а тільки шкоду, тому в першу чергу потрібні люди непідкупні, що для них матеріальні блага не грали б у житті першої ролі, і то однаково, чи справа йде про які-небудь дрібні вигоди, чи про якусь велику користь» $[6$, с. 158$]$. 
Виразні інституціальні підходи притаманні позиції видатного практика-кооператора та громадського діяча Юліана Павликовського. Як теоретик і практик господарської кооперації він сформувався під впливом молодшої історичної школи політичної економії, зокрема, віденського професора К. Гофмайстра, праць економістів Кембріджської Школи, а також німецьких й австрійських вчених, які були об'єднані у Союзі соціальної політики на чолі з Густавом фон Шмоллером. Юліан Павликовський добре був обізнаний із здобутками американської інституційної економічної школи, зокрема йому імпонувала точка зору цієї школи, відповідно до якої кожній нації є притаманними історично сформовані суспільно-економічні інституції й традиції, ці інституції і традиції обов'язково необхідно враховувати, коли відбуваються різні трансформаційні і модерністські зміни в господарській системі [2, с. 488].

Як теоретик і практик кооперативного руху, Юліан Павликовський особливу увагу звертав також на необхідність разом з еволюційним розвитком кооперативного руху для українців активно розвивати $\mathrm{i}$ національне приватне підприємництво. Він наголошував, що ці процеси повинні розвиватися одночасно, при цьому він зауважував, що результативність такої діяльності буде набагато вищою, коли будуть грамотно об'єднані зусилля і української кооперації, і приватного підприємництва. «Кожний нарід, як збірна одиниця, - писав Юліан Павликовський, - витворена спільнотою крови, спільнотою рідної культури і спільнотою ідей та змагань, мусить, щоби вдержати своє фізичне і духовне існування, щоби забезпечити собі відповідні умови постійного розвитку серед сім'ї цивілізованих народів світу, присвячувати господарській праці і організації власних господарських сил поважну частину своєї енергії» [8, с. 3].

Визначним не тільки українським, але і європейським кооператором $є$ також Сергій Васильович Бородаєвський, який був як теоретиком, так і практиком української кооперації, брав участь в міжнародних кооперативних з'їздах, був дійсним членом Міжнародного Кооперативного Союзу, постійно підтримував тісні контакти з сучасними йому видатними кооператорами світу. Про його європейське визнання свідчить те, що коли видатний французький теоретик і організатор кооперації Шарль Жід створив Інститут для Кооперативних Студій, то Сергій Бородаєвський став одним з перших його членів. Разом з тим, він володів енциклопедичними знаннями з проблем кооперативного руху, глибоко аналізував, узагальнював та робив висновки, використовуючи міжнародний досвід становлення та розвитку кооперативного руху. Про його надзвичайно продуктивну працю i, зрозуміло, європейське визнання свідчать, наприклад, понад півтисячі його фахових статей, які були опубліковані у 22 країнах тільки протягом 1941-1942 років. Ці публікації були надруковані у 85 кооперативних виданнях (українських, польських, чеських, болгарських, румунських, англійських, французьких, німецьких, іспанських, італійських, китайських, швейцарських та інших).

Чи не найважливішою серед численних праць Сергія Бородаєвського є монографія «Історія кооперації» [1]. Саме у цій важливій науковій праці вчений з використанням порівняльного аналізу показав особливості кооперації у понад 40 країнах світу, при цьому такий порівняльний аналіз було вперше зроблено у світовій кооперативній літературі.

Серед теоретиків і практиків кооперації дуже популярною була також книжка Сергія Бородаєвського «Збірник про дрібний кредит», яка обгрунтовувала інституційний підхід до кредитних відносин. Дана праця видатного вченого, яка з'ясовувала суть, закони, організацію та діловодство ощадно-позичкових i кредитних кас, видавалася шість разів загальним накладом 30 тис. примірників.

Отже, історичні еволюційні зміни в господарській самоорганізації українців носили чітко інституційне забарвлення, в основі якого яскраво переважали національно-визвольні стимули. Це було визначальним і першочерговим як для науковців-теоретиків української кооперації, так і для реальних фахових практиків українського господарського розвитку.

Висновки і перспективи подальших досліджень у даному напрямі. Українська кооперативна теорія дала багато постатей світовій економічній науці, яка розвивала і утверджувала інституціоналізм як напрям у світовій економічній науці, проте інституціоналізм розвивався і на національному грунті. Особливості українського національного інституціоналізму проявляються саме в тому, що інституціоналізм характеризується як морально-культурним, так і соціально-психологічним аспектами. Це дозволило розкрити по-новому і збагатити як українську економічну думку та господарсько-кооперативну практику, так і теорію інституціоналізму загалом.

Перспективними для подальших досліджень $є$ проблеми становлення та формування інституціоналізму в загальноукраїнських масштабах та його вплив на розвиток сучасної економічної думки в Україні. 


\section{ЛІТЕРАТУРА}

1. Бородаєвський С. В. Історія кооперації / С. В. Бородаєвський. - Прага : Український громадський видавничий фонд, 1925. - $446 \mathrm{c.}$

2. Вербова О. С. Національний господарський рух на західноукраїнських землях у 1848-1944 роках у контексті інституціоналізму / О. С. Вербова // Формування ринкової економіки : збірник наукових праць. - Спецвипуск : Методологічні проблеми сучасної політичної економії. - К. : КНЕУ, 2011. - С. 484-491.

3. Витанович І. Історія українського кооперативного руху / І. Витанович. - Нью-Йорк : ТУК, 1964. - 624 с.

4. Злупко С. М. Михайло Туган-Барановський - український економіст світової слави. - Львів : Каменяр, 1993. -192 c.

5. Злупко С. М. Історія економічної теорії : підручник / С. М. Злупко. - К. : Знання, 2005. - 719 с.

6. Мартос Б. Теорія кооперації : курс лекцій / Б. Мартос. - Регенсбург, Берхтесгаден : Український технічногосподарський інститут, 1947. - 165 с.

7. Норт Д. Інституції, інституціональні зміни та функціонування економіки / Д. Норт. - К. : Основи, $2000 .-198$ с.

8. Павликовський Ю. Кооперація і приватники / Ю. Павликовський // Торговля і Промисл. $-1934 .-1$ жовтня. Ч. 1. - C. 2-3.

9. Пал Л. А. Аналіз державної політики / Л. А. Пал. - К. : Основи, 1999. - 422 с.

10. Селигмен Б. Основные течения современной экономической мысли / Б. Селигмен. - М. : Наука, $1968 .-600$ с. 11. Туган-Барановский М. И. Социальные основы кооперации / М. И. Туган-Барановский. - М. : Экономика, 1989. - 496 c.

12. North D. C. Structure and Change in Economic History / D. C. North. - New York : Norton \& Company, 1981.

\section{REFERENCES}

1. Borodayevskyy, S. V. (1925) “History of Cooperation”, Prague, Ukrainian publishing public fund.

2. Verbovyi, A. (2011) "National economic movement in Western Ukraine in 1848-1944 years in the context of institutionalism”, Formation of market economy: technologies, Special Issue: Methodological problems of modern political economy, Kyiv, Ukraine, pp. 484-491.

3. Vytanovych, I. (1964) "History of Ukrainian cooperative movement", New York, USA

4. Zlupko, S. M. (1993) “Michael Tugan-Baranovsky - Ukrainian Economist of World Fame”, Lviv, Ukraine.

5. Zlupko, S. M. (2005) "History of Economic Theory: a Textbook”, Kyiv, Ukraine.

6. Martos, B. (1947) "Cooperation Theory: Lectures”, Regensburg Berchtesgaden.

7. North, D. (2000) "Institutions Change and the Economy”, Kyiv, Ukraine.

8. Pavlykovsky, J. (1934) "Cooperation and Private Traders”, Trade and Industry, vol. 1, pp. 2-3.

9. Pal, L. A. (1999) "Public Policy Analysis”, Kyiv, Ukraine.

10. Selihmen, B. (1968) "The Main Flows of Modern Economic Thought”, Moscow, Russia.

11. Tugan-Baranovsky, M. I. (1989) "Social Principles of Cooperation”, Moscow, Russia.

12. North, D. C. (1981) “Structure and Change in Economic History”, New York, Norton \& Company. 